\title{
To Study the Effect of Hydroxyurea on Frequency of Blood Transfusion in Sickle Cell Anemia
}

\author{
Dr. Swati Joshi, $\mathrm{MD}^{1 *}$, Dr. Dharmanshu Chaube, $\mathrm{MD}^{2}$
}

${ }^{1}$ PGMO, Pediatrics, PC Sethi Hospital, Indore, Madhya Pradesh, India

${ }^{2}$ Assistant Professor, Department of Pediatrics, MGM Medical College, Indore, Madhya Pradesh, India

DOI: $10.36347 /$ sjams.2020.v08i08.026

| Received: 11.08.2020 | Accepted: 25.08.2020 | Published: 28.08.2020

*Corresponding author: Dr. Swati Joshi, MD

Abstract

Original Research Article

Background: Sickle cell anemia (SCA) is a severe haematological disorder with substantial morbidity and mortality. Hydroxyurea is a potent inducer of fetal haemoglobin, and the past evidence has documented its laboratory and clinical efficacy for both adults and children with SCA. Objectives: To study the effect of hydroxyurea on frequency of blood transfusion in sickle cell anemia over a period of 6 months. Material and methods: A cohort study was carried out on 50 children with sickle cell anemia at Department of Pediatrics, MGM Medical College Indore from November 2018 to November 2019. Patients with sickle cell anemia between 2 to 14 years were included in this study. Effect of hydroxyurea was analyzed on frequency of blood transfusion and hospitalization in patients with sickle cell anemia. Results: $18 \%$ patients became transfusion free post HU therapy. HU leads to a significant reduction in rates of blood transfusion and hospitalization Conclusion: HU is efficacious in children with SCD and leads to a significant reduction in frequency of blood transfusion and hospitalization and thus improves the quality of life.

Keywords: Hydroxyurea Blood Sickle Cell Anemia.

Copyright @ 2020: This is an open-access article distributed under the terms of the Creative Commons Attribution license which permits unrestricted use, distribution, and reproduction in any medium for non-commercial use (NonCommercial, or CC-BY-NC) provided the original author and source are credited.

\section{INTRODUCTION}

Sickle cell disease (SCD) is an autosomal recessive inherited hemoglobinopathy caused due to substitution of the amino acid valine for glutamic acid at the sixth position on the beta globin chain. This results in formation of Hemoglobin $\mathrm{S}(\mathrm{HbS})$ which gets polymerized when it is deoxygenated [1] with subsequent cellular dehydration, altering the shape of the erythrocyte membrane into a sickled form. These rigid and deformed sickle erythrocytes have a shortened lifespan and undergo both intravascular and extravascular hemolysis, vaso-occlusion leading to acute tissue hypoxia and chronic organ damage. Clinical manifestations of SCA include acute vasoocclusive events, chronic hemolytic anemia, and organ dysfunction due to repeated sickling episodes.

$\mathrm{HbF}$ restricts the intracellular polymerization of sickle hemoglobin, hence, it has a positive impact on $\mathrm{SCD}$. Hydroxyurea was identified as a potent $\mathrm{HbF}$ inducer and was subsequently found to be both a feasible and effective treatment option for SCA [2]. Hydroxyurea is a cytotoxic, antimetabolic, and antineoplastic agent that has been used to treat a variety of medical disorders, most notably myeloproliferative neoplasms [3, 4] like chronic myeloid leukaemia [5]
Several mechanisms have been proposed, most notably the cytotoxic effects of hydroxyurea resulting in 'stress erythropoiesis' with increased HbF levels [6]. Hydroxyurea also has complex effects involving the production of nitric oxide and the soluble guanylyl cyclase and cGMP-dependent protein kinase pathway, that play a role in induced expression of the $\gamma$-globin gene [7-9]. Hydroxyurea not only increases $\mathrm{HbF}$ levels but also improves erythrocyte morphology and deformability, lowering of circulating leukocyte and reticulocyte counts, reduction in hemolysis, and potentially local release of nitric oxide leading to improved clinical outcomes.

\section{MeTHODS}

In this cohort study, 50 children between 2-14 years were included. The criteria for enrolment were children having sickle cell disease (confirmed by $\mathrm{Hb}$ electrophoresis) and written consent for participating in the study. Patients were excluded if they had active liver disease or creatinine more than $1.5 \mathrm{mg} / \mathrm{dl}$.

Specific proforma was designed for all children undergoing hydroxyurea therapy and demographic data such as age, sex and duration of disease, age at diagnosis, were recorded. 
Clinical manifestations of patients such as frequency of vasoocclusive crisis, chest pain syndrome, stroke, the number of hospitalizations and frequency of transfusions were recorded.

Blood tests such as $\mathrm{CBC}, \mathrm{Hb}$ electrophoresis (HbF levels), liver and kidney function tests were performed for all patients before treatment and repeated periodically. Then hydroxyurea $15 \mathrm{mg} / \mathrm{kg} /$ day was administered for 6 months. CBC was monitored every 15 days and liver and renal functions were done monthly. Toxicity for this drug was defined as follows: ANC $<1500 / \mu 1$, Platelets less than $75000 \mu 1$, Hemoglobin less than $4 \mathrm{~g} / \mathrm{dL}$. In case of toxicity with any of the above criteria, the drug was discontinued and after normalization of complete blood cell count, it was continued at minimum dose of $10 \mathrm{mg} / \mathrm{kg}$ of body weight.
Data were analyzed using SPSS version 21.

\section{Results}

Table-I: Sex wise distribution

\begin{tabular}{|l|l|}
\hline Gender & $\mathbf{N}(\boldsymbol{\%})$ \\
\hline Male & $32(64 \%)$ \\
\hline Female & $18(36 \%)$ \\
\hline Total & $50(100 \%)$ \\
\hline
\end{tabular}

In this study 50 patients with sickle cell disease were treated with $\mathrm{HU}$ and evaluated. These patients consisted of 32 males and 18 females. The minimum age was 2 and the maximum was 14 .

Table-II: Mean age at diagnosis

\begin{tabular}{|l|l|}
\hline Gender & Age(years) \\
\hline Male & 4.8 \\
\hline Female & 4.1 \\
\hline
\end{tabular}

Table-III: No. Of Patients Receiving Blood Transfusion Pre and Post Treatment

\begin{tabular}{|c|l|l|l|}
\hline \multicolumn{2}{|c|}{ Variable } & \multicolumn{2}{c|}{ Sickle Cell Disease } \\
\cline { 3 - 4 } \multicolumn{2}{|c|}{} & Pre-Treatment & 30 \\
\hline \multirow{2}{*}{ Transfusion } & Yes & 39 & 20 \\
\cline { 2 - 4 } & No & 11 & 2 Treatment \\
\hline
\end{tabular}

$18 \%$ patients became transfusion free post HU therapy

Table-IV: Frequency of hospital admissions 6months before and after hydroxyurea therapy

\begin{tabular}{|l|l|l|}
\hline & Mean & \multirow{2}{*}{ P value $<\mathbf{0 . 0 0 1}$} \\
\cline { 1 - 2 } No of admissions 6 months before hydroxyurea therapy & 2.1 & \multirow{3}{*}{} \\
\cline { 1 - 2 } No of admissions 6 months after hydroxyurea therapy & 0.7 & \\
\hline Difference & 1.4 & \\
\hline
\end{tabular}

HU causes a significant decrease in hospitalization rates

Table-V: Frequency of blood transfusions 6 months before and after hydroxyurea therapy

\begin{tabular}{|l|l|l|}
\hline & Mean & \\
\hline No of transfusions 6 months before hydroxyurea therapy & 3.88 & \multirow{2}{*}{ P value $<0.001$} \\
\cline { 1 - 2 } No of transfusions 6 months after hydroxyurea therapy & 2.77 & \\
\cline { 1 - 2 } Difference & 1.11 & \\
\hline
\end{tabular}

HU causes a significant reduction in blood transfusion rates

\section{DISCUSSION}

Hydroxyurea is currently the mainstay of therapy in sickle cell anaemia. Our study shows a significant reduction in frequency of blood transfusion with hydroxyurea therapy. It also improves the quality of life as it reduces the episodes of vasoocclusive crisis and acute chest syndrome leading to a significant reduction in hospitalization rate. Previous studies also show similar results.
5 RCTs in past have shown the efficacy of hydroxyurea in patients with SCA [10-14]. With the exception of the SWiTCH trial, these other RCTs described a benefit for patients receiving hydroxyurea compared with the standard of care. The MSH study reported reduced frequency of VOC, ACS, and transfusions [10]. A small RCT from India reported a significant decrease in the number of VOC, transfusion requirements, and hospitalizations with hydroxyurea compared with placebo despite high baseline $\mathrm{HbF}$ levels and low-dose therapy [13]

Our study also shows a significant role of hydroxyurea in reducing frequency of blood transfusions and hospitalization in sickle cell anaemia and thus improves the quality of life in these patients. 
Our study has been done on a small sample size for a short follow up period of 6 months so more studies with large sample size and longer follow up period are required to assess the toxicity, adverse effects, mortality and efficacy of hydroxyurea in sickle cell disease.

\section{Conclusion}

HU is efficacious in children with SCD with reduction in hospitalizations and frequency of blood transfusion. However, the paucity of long-term studies limits conclusions about toxicities and mortality.

\section{REFERENCES}

1. Inati A, Koussa S, Taher A, Perrine S. Sickle cell disease: new insights into pathophysiology and treatment. Pediatr Ann. 2008 May; 37(5):311-21.

2. Platt OS, Orkin SH, Dover G, Beardsley GP, Miller B, Nathan DG. Hydroxyurea enhances fetal hemoglobin production in sickle cell anemia. The Journal of clinical investigation. 1984 Aug 1;74(2):652-6.

3. Cortelazzo S, Finazzi G, Ruggeri M, Vestri O, Galli M, Rodeghiero F, Barbui T. Hydroxyurea for patients with essential thrombocythemia and a high risk of thrombosis. New England Journal of Medicine. 1995 Apr 27;332(17):1132-7.

4. Campbell PJ, Green AR. The myeloproliferative disorders. N Engl J Med. 2006;355(23):2452-2466.

5. Kennedy BJ, Yarbro JW. Metabolic and therapeutic effects of hydroxyurea in chronic myeloid leukemia. JAMA. 1966;195(12):1038-1043.

6. Mabaera R, West RJ, Conine SJ, Macari ER, Boyd $\mathrm{CD}$, Engman $\mathrm{CA}$, Lowrey $\mathrm{CH}$. A cell stress signaling model of fetal hemoglobin induction: what doesn't kill red blood cells may make them stronger. Experimental hematology. 2008 Sep 1;36(9):1057-72.

7. Cokic VP, Smith RD, Beleslin-Cokic BB, Njoroge JM, Miller JL, Gladwin MT, Schechter AN.
Hydroxyurea induces fetal hemoglobin by the nitric oxide-dependent activation of soluble guanylyl cyclase. The Journal of clinical investigation. 2003 Jan 15;111(2):231-9.

8. Cokic VP, Andric SA, Stojilkovic SS, Noguchi CT, Schechter AN. Hydroxyurea nitrosylates and activates soluble guanylyl cyclase in human erythroid cells. Blood, The Journal of the American Society of Hematology. 2008 Feb 1;111(3):111723.

9. Ikuta T, Ausenda S, Cappellini MD. Mechanism for fetal globin gene expression: role of the soluble guanylate cyclase-cGMP-dependent protein kinase pathway. Proc Natl Acad Sci. 2001;98(4):18471852.

10. Charache S, Terrin ML, Moore RD, Dover GJ, Barton FB, Eckert SV, McMahon RP, Bonds DR, Investigators of the Multicenter Study of Hydroxyurea in Sickle Cell Anemia. Effect of hydroxyurea on the frequency of painful crises in sickle cell anemia. New England Journal of Medicine. 1995 May 18;332(20):1317-22.

11. Wang WC, Ware RE, Miller ST, Iyer RV, Casella JF, Minniti CP, Rana S, Thornburg CD, Rogers ZR, Kalpatthi RV, Barredo JC. Hydroxycarbamide in very young children with sickle-cell anaemia: a multicentre, randomised, controlled trial (BABY HUG). The Lancet. 2011 May 14;377(9778):166372.

12. Ware RE, Helms RW SWiTCH Investigators. Stroke With Transfusions Changing to Hydroxyurea (SWiTCH). Blood. 2012;119(17):3925-3932

13. Jain DL, Sarathi V, Desai S, Bhatnagar M, Lodha A. Low fixed-dose hydroxyurea in severely affected Indian children with sickle cell disease. Hemoglobin. 2012;36(4):323-332

14. Ferster A, Vermylen C, Cornu G, Buyse M, Corazza F, Devalck C, Fondu P, Toppet M, Sariban E. Hydroxyurea for treatment of severe sickle cell anemia: a pediatric clinical trial.1996. 